\title{
Voorbeelde van kulturele artefakte in die voorbereiding van 'n wiskundeles
}

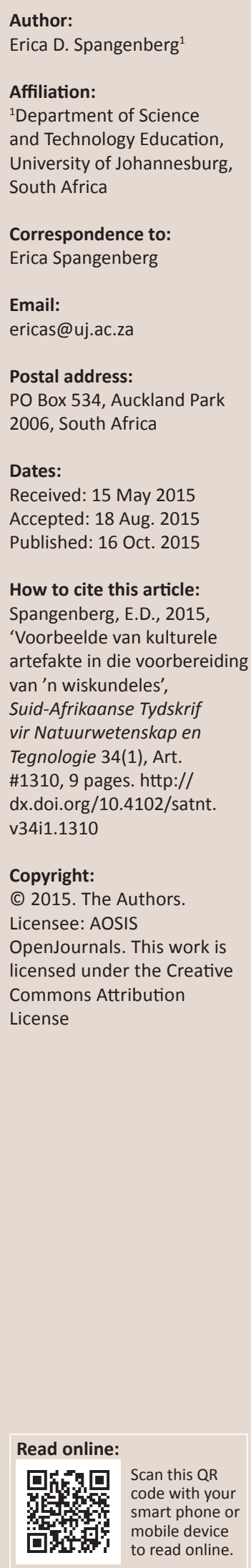

Suid-Afrika met sy diverse kulturele groepe leen hom tot 'n ryk verskeidenheid kulturele artefakte wat op wiskunde gebaseer is. Wiskunde word onder meer volgens die Verdere Onderwys- en Opleidingkurrikulum- en assesseringsbeleidsverklaring gedefinieer as 'n menslike aktiwiteit wat wiskundige ondersoeke in fisiese en sosiale verskynsels insluit en goed aanpas by etnowiskunde. Onderwysers uit die verskillende kulturele groepe se kennis oor kulturele artefakte is egter beperk en daar word nie voldoende aandag tydens die opleiding van onderwysers hieraan gewy nie. Dié artikel het ten doel om voorbeelde van kulturele artefakte in die voorbereiding van 'n wiskundeles te ondersoek. Die studie is gesitueer in 'n sosio-kulturele konteks. Negentien wiskunde-onderwysstudente uit verskillende kulturele groepe, wat ingeskryf is vir 'n B.Ed.-honneursgraad in wiskunde-onderwys, is genooi om deel te neem. ' $n$ Kwalitatiewe navorsingsontwerp is gebruik, met navorsingsverslae en eentot-een-onderhoude as data-insamelingsinstrumente. Die wiskunde-onderwysstudente het 'n navorsingsprojek uitgevoer wat van hulle vereis het om kulturele artefakte in 'n wiskundeles in te sluit. Die data is geanaliseer volgens temas, subtemas en kodes. Daar is bevind dat die deelnemers verskillende voorbeelde van kulturele artefakte gebruik het wat kulturele vestings, kledingstukke, speletjies en kunswerke insluit. Die artikel dra by tot die bekendstelling van kulturele artefakte in 'n wiskundeles.

Examples of cultural artefacts in the preparation of a mathematics lesson. South Africa, with its diverse cultural groups, has a rich variety of cultural artefacts based on mathematics. Mathematics, according to the Curriculum and Assessment Policy Statement for Mathematics in the Further Education and Training Phase, is defined as a human activity, which includes mathematical investigations in physical and social phenomena, well aligned with ethno mathematics. Teachers from various cultural groups, however, have limited knowledge of cultural artefacts and this knowledge does not receive sufficient attention during teacher training. The purpose of this article is to investigate examples of cultural artefacts in the preparation of a mathematics lesson. The study is situated in a socio-cultural context. Nineteen mathematics student-teachers from different cultural groups enrolled for a B.Ed. Honours degree, were invited to participate. A qualitative research design, with research reports and one-on-one interviews as data collection instruments, was adopted. The mathematics studentteachers conducted a research project that expected from them to include cultural artefacts in a mathematics lesson. The data was analysed according to themes, subthemes and codes. Findings reveal that participants used different examples of cultural artefacts, which include cultural dwellings, clothing, games and artworks. The article contributes to the introduction of cultural artefacts in a mathematics lesson.

\section{Inleiding en agtergrond}

Hoewel Suid-Afrika 'n diverse land is wat ryk is aan verskillende kulture en tale, word wiskunde dikwels as 'n Westerse vak met min kulturele inhoud of waardes beskou en word onderrig as 'n objektiewe, abstrakte handeling gereken (Nkopodi \& Mosimege 2009). Met Suid-Afrika se 11 amptelike tale en onderskeie kulturele groepe, ryk kulturele artefakte, tradisionele speletjies en Afrika-musiek, word gulde geleenthede vir die gebruik van etnowiskunde in die wiskundeklas gebied. Wiskunde is 'n menslike aktiwiteit wat in die alledaagse lewe van gemeenskappe gebruik word soos tydens die berekening van kleingeld by supermarkte; in die opstel van huishoudelike begrotings; by die balansering van bankstate en in speletjies (Selin 2000). Wiskunde daarteenoor, is ook 'n wetenskap wat abstrakte konsepte insluit en in dissiplines soos Fisika en Ingenieurswetenskappe toegepas word (Soanes 2002).

Suid-Afrika se leerders presteer in die algemeen swak in wiskunde. In 'n internasionaal gestandaardiseerde toets vir graad 8-leerders wat elke vierde jaar afgeneem word, naamlik die 
Trends in International Mathematics and Science Study (TIMSS), het Suid-Afrikaanse leerders in 2011 die swakste van al die deelnemende middelinkomste-lande gevaar (Spaull 2013). Van die redes vir dié swak prestasie kan dalk 'n tekort aan wiskunde-onderwysers wees of dat sommige onderwysers onvoldoende wiskundevakkennis besit. Volgens Adler en Davis (2006) het Suid-Afrika 'n tekort aan gekwalifiseerde wiskunde-onderwysers omdat baie wiskunde-onderwysers nie die geleentheid het om hulself verder in wiskunde te bekwaam nie. Moloi en Strauss (2005) beaam dié tekort aan wiskunde-onderwysers, veral in vakke soos wiskunde, wetenskap en tegnologie en volgens Bernstein (2011) lewer Suid-Afrika jaarliks slegs ongeveer 'n derde van sy behoefte aan nuwe onderwysers in dié vakke op.

Wiskunde kan in drie dimensies verdeel word, naamlik inhoud, proses en kultuur (Wong 2005). Die inhoud sluit vakkennis van wiskunde-onderwerpe en wiskundevaardighede in. Wiskunde is gebaseer op prosesse soos wiskundige denke, ontdekkings in wiskunde, voorspelling van wiskundige verskynsels, gevolgtrekkings vanuit wiskundige teorieë, probleemoplossing en om sin te maak van die wêreld bestaande uit getalle, meting, meetkunde en simbole. Kultuur verwys na aspekte van wiskunde eerder as wiskunde self, soos die geskiedenis van wiskunde, verhale oor wiskundiges, wiskunde in literêre werke en films, die filosofie van wiskunde, die sosiale impak van wiskunde en persepsies van wiskunde. Dit is dus moontlik om die raamwerk van skoolwiskunde in Suid-Afrika te verbreed deur ' $n$ kulturele perspektief in te sluit, soos om te fokus op voorbeelde van kulturele artefakte in die voorbereiding van wiskundelesse. Bullivant (1987) argumenteer dat kultuur ' $n$ algemene samestelling is van interafhanklike, waardegedrewe, tradisionele kennis en huidige openbare kennis wat in gedrag en artefakte omvat word en aan nuwe lede oorgedra word deur tekens en simbole vanuit vorige generasies om betekenis te gee aan toekomstige uitdagings. Etnowiskunde behels juis die integrering van wiskundekonsepte en -praktyke van verskeie kulture in formele skoolwiskunde (Adam, Alangui \& Barton 2003).

Wiskunde-onderwysers behoort oor inheemse kennis te beskik indien hulle voorbeelde van kulturele artefakte in wiskundelesse wil gebruik. Inheemse kennis word ongelukkig steeds in die meeste Suid-Afrikaanse wiskundeklasse afgeskeep omdat "n groot persentasie onderwysers nie oor die nodige kennis of vaardigheid' beskik om inheemse kennis te onderrig nie, al het onderwysers die 'sosiale aanspreeklikheid [om] hulle leerders bewus [te] maak van die kulturele en praktiese waarde van inheemse kennis' (De Beer \& Van Wyk 2012:4). Inheemse kennis vorm inherent deel van die mens se bestaan.

As 'n ervare wiskunde-onderwyser het die navorser waargeneem dat hoewel wiskunde-onderwysers soms poog om kulturele kontekste in te sluit, dit nie spontaan plaasvind nie. Wiskunde word dikwels as 'n abstrakte, gedekontekstualiseerde, kultuurvrye vak aangebied. Sekere kontekste is waargeneem waar onderwysers met beperkte kennis van wiskunde die vak onderrig en geneig is om prosedures te oorbeklemtoon en dan begrip inboet. Daar word ook deurentyd van leerders verwag om prosedures, reëls en formules sonder begrip te memoriseer, wat hulle dan maklik weer vergeet en wat lei tot paniek by leerders. Hierdie onderrigroetines is van die bydraende faktore wat tot swak leerderprestasie in Wiskunde lei. Die gebruik van inheemse kennis kom gevolglik nie tot sy reg in wiskunde nie, hoewel daar toenemende literatuurstudies is wat argumenteer dat wiskunde-onderrig wat in lewenswerklike kulturele praktyke gesetel is, leerders kan help om met wiskunde in hul alledaagse lewes te assosieer en dit daarin te integreer sodat hulle die vak kan geniet, wat weer tot beter resultate sal lei (Ascher \& D'Abrosio 1994; Bishop 1991; Wong 2005).

Ongeag die belangrike rol wat onderwysers in die onderrig van wiskunde speel en die feit dat wiskunde 'n menslike aktiwiteit is, het onderwysers beperkte kennis van hoe om kulturele aktiwiteite in wiskundelesse in te sluit. Dit is dus belangrik om in die lig van navorsing in etnowiskunde (Bullivant 1987; D'Ambrosio 1990; Rosa \& Orey 2011; Rowlands \& Carson 2002; Wong 2005), aandag te skenk aan voorbeelde van kulturele artefakte in die voorbereiding van wiskundelesse ten einde wiskunde meer betekenisvol en kontekstueel aan leerders te onderrig. Die navorsingsvraag is: Watter voorbeelde van kulturele artefakte gebruik wiskunde-onderwysers wat honneurs in opvoedkunde volg in die voorbereiding van 'n wiskundeles, en hoe ervaar leerders dié lesse?

\section{Konseptueel teoretiese raamwerk}

Die navorser gaan vervolgens 'n konseptueel teoretiese raamwerk aanbied om die verband tussen wiskunde, etnowiskunde en kulturele artefakte in oënskou te neem, soos geillustreer in Figuur 1.

Wiskunde is 'n akademiese vak wat in skole wêreldwyd aangebied word. Wiskunde sluit onder meer etnowiskunde in, waarvan kultuur die basis vorm (Wong 2005). Etnowiskunde kan in die wiskundeklas gestalte vind deur

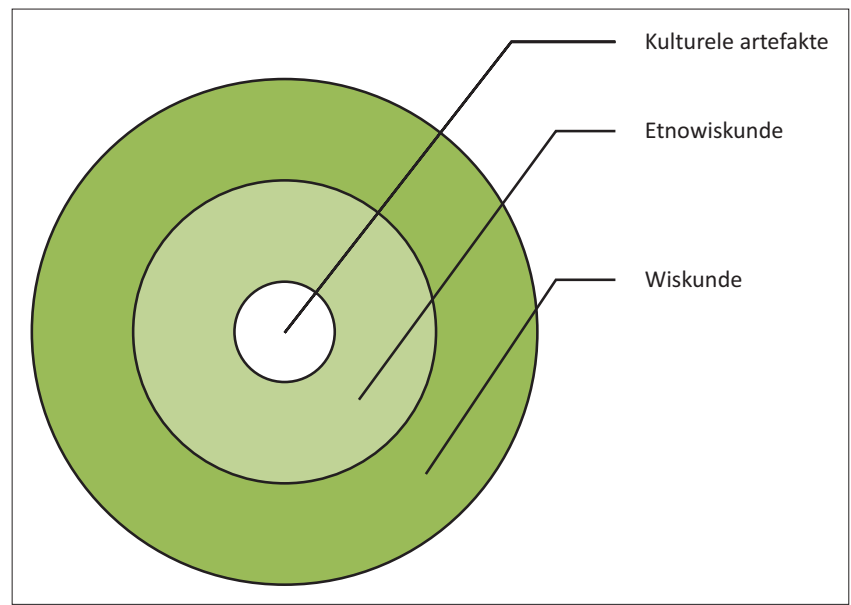

FIGUUR 1: Die verband tussen wiskunde, etnowiskunde en kulturele artefakte. 
die gebruik van kulturele artefakte in die voorbereiding van wiskundelesse. Die konsepte soos geillustreer in Figuur 1 word vervolgens bespreek.

\section{Wiskunde}

Mense word gebore met talente om logies te redeneer, simbole te manipuleer en raaisels te geniet (Wong 2005). Wiskunde as 'n objektiewe realiteit is baie jare suksesvol nagevors en toegepas in die wetenskappe en ingenieurswese, terwyl daar ' $n$ tekort is aan ondersoeke na die rol van wiskunde in die modellering van sosiale, politieke en kulturele verskynsels wat menslike interaksies en waardes insluit. Waar wiskunde daagliks deur kulturele groepe op 'n informele wyse gebruik word, word die waarde daarvan deur navorsers onderskat.

In Suid-Afrika word wiskunde dikwels as 'n suiwer akademiese vak beskou wat op vakinhoud en die toepassing daarvan fokus (Venkat 2007). Bohlmann en Pretorius (2008:43) voeg by dat wiskunde 'n abstrakte, deduktiewe vak is wat deur die wetenskaplike, tegnologiese en ingenieurswêreld vereis word. Die navorser verskil van dié siening en beskou wiskunde as 'n vak wat 'n belangriker rol in baie fasette van die kulturele lewe, soos in kuns, speletjies en musiek, speel. Beskouings van wiskunde as 'n abstrakte, logiese Westerse wetenskap onderskat wiskunde se rol as menslike aktiwiteit in konkrete, lewenswerklike situasies. Die Verdere Onderwys- en Opleidingkurrikulumen assesseringsbeleidsverklaring (KABV) van Suid-Afrika (Departement van Basiese Onderwys [DBO] 2011b) verbind wiskunde ook met menslike aktiwiteit deur wiskunde te definieer as:

\footnotetext{
... 'n taal wat gebruik maak van simbole en notasies om numeriese, meetkundige en grafiese verwantskappe te beskryf ... 'n menslike aktiwiteit wat waarneming, voorstelling en ondersoek na patrone en kwalitatiewe verwantskappe in fisiese en maatskaplike verskynsels sowel as tussen wiskundige voorwerpe behels ... om die wêreld (fisies, maatskaplik en ekonomies) te verstaan. (bl. 8)
}

Die bogenoemde definisie van wiskunde impliseer 'n verbintenis tussen die mens en sy wêreld, hoewel die vak nie altyd sodanig onderrig word nie en baie onderwysers nie die kundigheid het om dit te doen nie.

\section{Etnowiskunde}

Etnowiskunde kan beskou word as die kultuurspesifieke aard van wiskunde, sowel as die wiskunde wat deur kulturele groepe beoefen word (Namukasa 2004). Etnowiskunde vorm deel van ' $n$ breër raamwerk van geskiedkundige gebeure en is nooit staties nie, maar ontwikkel met verloop van tyd (D’Ambrosio 1989). Kulturele groepe se identiteit hang hoofsaaklik van die fokus van hul belange, motivering en sekere kodes en spreekwyses af ( $D^{\prime}$ Ambrosio 1990). Etnowiskunde fokus op 'n menslike aktiwiteit, naamlik die doen van wiskunde, en wel soos dit deur kultuurgroepe in hul alledaagse lewes beoefen word (Rowlands \& Carson 2002). Om wiskundige denkwyses in kulturele groepe te ondersoek en om wiskundeleerders te help om beide die universele aard van menslike kreatiwiteit en die verskeidenheid van uitdrukkingsvorme in verskillende kulture te verken (Rowlands \& Carson 2002), is tendense wat deur sommige wiskunde-onderwysers voorgestaan word (Wong 2005). Adam et al. (2003) argumenteer dat etnowiskunde wiskundekonsepte en verskeie kulturele praktyke in formele skoolwiskunde met mekaar verbind.

Volgens Rosa en Orey (2011:35) se definisie bestaan etnowiskunde uit drie konsepte, naamlik 'ethno', 'mathema' en 'tics'. Die woord etno is van etnisiteit afgelei, wat verwys na gemeenskaplike tale, kulture, geskiedenis, nasionaliteite en gelowe (Hall 1997). Volgens Rosa en Orey (2011:35) sluit die breë konsep 'ethno' alle kultureel identifiseerbare groepe met hul slagspreuke, kodes, simbole, mites en self spesifieke denkwyses en onderhandeling in. Kultuur is die resultaat van 'n hiërargie van gedrag. Individuele gedrag ontwikkel deur meganismes soos onderrig tot sosiale gedrag en tot die generering van kulturele gedrag. 'Mathema' beteken om die wêreld te verduidelik en die realiteit te bestuur sodat kultuurgroepe kan oorleef, terwyl 'tics' verwys na tegnieke soos tel, rangskik, sorteer, meet, weeg, klassifiseer en modelleer (Rosa \& Orey 2011:35). Volgens Rosa en Orey (2011:35) ontwikkel die 'mathema' die 'tics' binne die konteks van die 'ethnos'. Etnowiskunde is dus 'n studie oor hoe mense vanuit verskillende kulturele groepe tegnieke ontwikkel om betekenis aan hul wêreld te gee in reaksie op probleme en struikelblokke tydens hul menslike oorlewing (Rosa \& Orey 2011). Die definisies wat gegee is vir 'mathema' en 'tics' is nie universeel nie, maar geskep deur Rosa en Orey (2011).

Volgens D'Ambrosio (1985) word daar vanweë die wydverspreide beskouing oor die universaliteit van wiskunde nie baie op etnowiskunde gefokus nie. Daar is 'n sterk verband tussen wiskundekonsepte en die kulturele omgewing waarin wiskundige idees ontstaan. Gemeenskappe beoefen dikwels wiskundige idees soos optel, sortering en meting op maniere wat verskil van die wiskunde wat op skoolvlak aangebied word. Etnowiskunde bereik egter nie die vlak van matematisering wat van leerders op skoolvlak verwag word nie en ontwikkel en verander voortdurend vanweë sosiale veranderings in samelewings. Etnowiskunde poog om respek vir kulturele verskille en leerders se kulturele agtergrond te bevorder en bou wiskunde-onderrig nie noodwendig op 'n leerder se kulturele agtergrond nie (Rowlands \& Carson 2002). Een van die redes waarom die status van etnowiskunde bevraagteken word, is die Westerse invloede wat dikwels plaaslike kulturele gewoontes ontken. D'Ambrosio (1985) argumenteer egter dat wiskunde die natuurlike resultaat van evolusie binne-in 'n sosiale, ekonomiese en kulturele atmosfeer is.

\section{Kulturele artefakte}

Etnowiskunde bied aan leerders die geleentheid om die verband tussen wiskunde en hul onderskeie kulture in te sien deur van konkrete voorwerpe en kulturele artefakte (kunsvoorwerpe) uit die onderskeie gemeenskappe gebruik 
te maak (Adam et al. 2003). Die konsep kulturele artefak word in sosiale wetenskappe, spesifiek antropologie, etnologie en sosiologie, gebruik vir enigiets wat deur 'n spesifieke kultuurgroep geskep is en wat inligting oor die kultuur van die skepper of gebruikers daarvan verskaf (Bangura 2012). Dit is dus enige voorwerp of simbool waaraan ' $n$ mens vorm gegee het en wat 'n kultuurgroep verteenwoordig (Soanes 2002). Sulke voorwerpe word tradisioneel in gemeenskappe aangetref en sluit gereedskap, 'n kunswerk of 'n voorwerp van argeologiese belang in. 'n Onderwyser kan so 'n konkrete voorwerp of simbool, wat relevant tot leerders se alledaagse lewe is en waarmee hulle kan assosieer, gebruik om 'n lewenswerklike les aan te bied wat 'n beter begrip van wiskundige konsepte by leerders sal bevorder (Leonard 2008). Die onderrig van meetkundige vorms aan die hand van Ndebele kunswerke is ' $n$ voorbeeld hiervan.

\section{Onderwysersopleiding in etnowiskunde}

Etnowiskunde is belangrik omdat inheemse kennisstelsels (plaaslike kennis, uniek aan 'n spesifieke kultuur of samelewing) deel van die mens se leefwêreld is, hetsy deel van die menslike wese of liggaam (vergestalte [beliggaamde] kognisie), of direkte omgewing (gesitueerde kognisie) of in die sosiale omgang met mense (gedeelde kognisie) (Wilson 2002). Vergestalte (beliggaamde) kognisie verwys na verstandelike prosesse wat diep gewortel is in die mens se liggaamlike interaksie met die wêreld; gesitueerde kognisie na die kognitiewe aktiwiteit wat plaasvind in die konteks van 'n lewenswerklike omgewing; en gedeelde kognisie na die verspreiding van kognisie regoor die algehele interaktiewe situasie, insluitend die verstand, liggaam en omgewing (Wilson 2002). Ondanks die feit dat inheemse kennis hoog geag word deur die Nasionale Navorsingstigting (NNS) in Suid-Afrika, 'n raamwerkdokument om navorsing in inheemse kennisstelsels en die rol daarvan in die gemeenskap te bevorder en te ondersteun (NNS 2012), is die meeste wiskunde-onderwysers in Suid-Afrika nie opgelei om etnowiskunde te onderrig nie. Etnowiskunde word ook nie as 'n module by onderwysopleidingsinstitute in Suid-Afrika aangebied nie, al het baie onderwysers beperkte kennis van hoe om kulturele artefakte in lesaanbiedings te gebruik. Om wiskunde as 'n menslike aktiwiteit, soos volgens KABV (DBO 2011b) aan te bied, is dit belangrik om etnowiskunde in onderwysersopleiding in te sluit.

Die onderrig van wiskunde vanuit 'n kultuurperspektief bevorder die erkenning van kulturele erfenisse en lê 'n basis om leerders te help om wiskundige kennis te verstaan en te konseptualiseer (Ascher \& D'Abrosio 1994). Volgens Wong (2005) motiveer kulturele artefakte leerders om wiskunde te leer deur van 'n konkrete kulturele konteks van wiskunde gebruik te maak. Verder skep die gebruik van kulturele artefakte in die klaskamer ' $n$ motiverende leeromgewing waar leerders nie hoef te vrees om wiskunde te beoefen nie. D'Ambrosio (1989) beklemtoon die belangrikheid van die sosio-kulturele omgewing in die onderrig- en leerproses om te verseker dat leerinhoud relevant in leerders se alledaagse lewes is. Volgens Rosa en Orey (2011) is etnowiskunde 'n kragtige strategie om 'n leerder se werklike lewenservarings te meet en bied dit aan leerders die nodige middele om kritiese deelnemers in die gemeenskap te word. Selfs leerders met 'n vrees vir wiskunde word aangemoedig om meer positief teenoor wiskunde te wees wanneer hulle die bruikbaarheid daarvan deur middel van kulturele artefakte ontdek. Verder kweek etnowiskunde 'n bewustheid by leerders oor hoe die geskiedenis van die hedendaagse wiskunde gevorm is en help dit leerders om te begryp hoe wiskunde in die alledaagse lewe toegepas word.

Onderwysers kan leerders help om hul volle potensiaal te besef deur die belangrikheid van kultuur in die identiteitsontwikkeling van 'n leerder en die effek van kultuur op leerders se denke te erken. Volgens D'Ambrosio (1989) moet wiskunde relevant tot die leerbehoeftes en kulturele waardering van leerders gemaak word. Dit is ook belangrik dat onderwysers kulturele invloede op wiskunde verstaan. Verder moet leerders aangemoedig word om hul eie wiskundekonsepte te skep en te verduidelik, en onderwysers moet sodanige pogings respekteer en sodoende 'n positiewe selfbeeld ten opsigte van wiskunde by leerders help ontwikkel.

Leerders se sienings van die klaskameromgewing hou verband met emosionele ervarings soos genot, angs en woede (Frenzel, Pekrun \& Goetz 2007). Onderwysers kan deur middel van etnowiskunde 'n stimulerende, nieintimiderende omgewing vir leer skep wat op leerders se sterk punte voortbou (Hlalele 2012). Genotvolle leerervarings kan leerders se negatiewe sienings ten opsigte van wiskunde verander en omskep in entoesiasme om wiskunde te leer (Abramovich 2000). Etnowiskunde, en spesifiek die gebruik van kulturele artefakte, kan 'n onderwyser in staat stel om wiskunde op 'n verbeeldingryke en kreatiewe wyse aan te bied en te assesseer en sodoende onderrigkwaliteit verbeter. Frenzel et al. (2007) het gevind dat leerders se waarneming van die kwaliteit van onderrig positief met genotvolle ervarings en negatief met angs en woede korreleer.

Etnowiskunde kan 'n waardevolle bydrae lewer tot die kurrikulum, asook tot die bevordering van wiskundeprosesse soos probleemoplossing, deduktiewe en induktiewe beredenering, bewyse en wiskundige kommunikasie (Wong 2005), maar dit moet reeds in onderwysopleiding aangepak word.

\section{Navorsingsmetodologie Navorsingsontwerp}

Die belangrike rol wat onderwysers in die onderrig van wiskunde speel en die feit dat wiskunde deel van die alledaagse lewe van alle gemeenskappe is, maar wiskundebemeestering op skoolvlak in Suid-Afrika nie na wense is nie, het die navorser oortuig om 'n pragmatiese paradigma te volg wat besorg is oor wat werk en wat oplossings in 'n lewenswerklike situasie bied (Creswell 2003). In die studie is gefokus op 'n bepaalde tema, naamlik die 
gebruik van kulturele artefakte, om honneursstudente voor te berei om navorsing te kan doen. Die studie is gesitueer in 'n sosio-kulturele konteks met 'n kwalitatiewe benadering. Volgens Vandeyar (2010) behels sosiale ondersoeke oorwegings oor hoe sekere verskynsels of kennisvorme deur mense in aksie bereik word. Dié navorsingsontwerp is geskik, aangesien die studie onderwysers se ervarings ten opsigte van etnowiskunde ondersoek om die gebruik van kulturele artefakte in die voorbereiding van wiskundelesse te verstaan (Rowley 2002).

\section{Doel van die studie}

Die doel van die artikel is om voorbeelde van kulturele artefakte te identifiseer wat honneursstudente in die voorbereiding van 'n wiskundeles gebruik het ten einde blootstelling te gee aan hoe om navorsing te doen en om wiskunde meer betekenisvol en kontekstueel aan leerders te onderrig.

\section{Steekproef}

'n Doelgerigte steekproeftegniek (Creswell 2003) is gebruik om 19 wiskunde-onderwysstudente wat terselfdertyd ingeskrewe honneursstudente by 'n universiteit in SuidAfrika is, uit te nooi. Die deelnemers moes heeltydse wiskunde-onderwysers, en dus deeltydse studente, wees en vir wiskunde-onderwys ingeskryf wees. Deelname was vrywillig. Tabel 1 dui elemente van hul demografiese agtergrond aan.

Die meerderheid deelnemers is swart $(78.9 \%)$ en inheemse moedertaalsprekers (78.9\%). Ongeveer die helfte van die deelnemers is vroulik $(47.5 \%)$. Slegs $84.2 \%$ het hul navorsingsverslae elektronies op 'n laserskyf ingehandig, waarvan slegs $57.9 \%$ van die laserskywe oopgemaak kon word en bruikbaar was.

\section{Etiese oorwegings}

Die etiese komitee van die Fakulteit van Opvoedkunde van die universiteit het etiese klaring vir die studie toegestaan en toestemming is verkry van skole om die navorsing uit te voer. Deelname was vrywillig; toestemming is verkry om

TABEL 1: Demografiese agtergrond van deelnemers.

\begin{tabular}{llcc}
\hline Profiel veranderlike & Deelnemers & $\boldsymbol{N}$ & $\mathbf{\%}$ \\
\hline Geslag† & Vroulik & 9 & 47.3 \\
& Manlik & 10 & 52.7 \\
Etniese groep $\dagger$ & Asiaties, insluitend Indiër & 1 & 5.3 \\
& Bruin & 3 & 15.8 \\
& Swart & 15 & 78.9 \\
& Wit & 0 & 0.0 \\
Moedertaal $\dagger$ & Afrikaans & 1 & 5.3 \\
& Engels & 3 & 15.8 \\
& Inheems & 15 & 78.9 \\
Navorsingsverslae $\dagger$ & Ingehandig en bruikbaar & 11 & 57.9 \\
& Ingehandig, maar nie bruikbaar nie & 5 & 26.3 \\
& Nie ingehandig nie & 3 & 15.8 \\
\hline
\end{tabular}

onderhoude met leerders te voer en deelnemers se identiteit is beskerm (Mouton 2001).

\section{Geldigheid en betroubaarheid}

Geldigheid is verseker deur data deur middel van dataversadiging en kristallisasie te bevestig en nuwe fasette wat van die data ontstaan het, toe te laat. Meer as een databron, naamlik navorsingsverslae van deelnemers en onderhoude met leerders, is gebruik om interne geldigheid (Guba 1981) te verseker. Betroubaarheid is verhoog deur inligting vanuit onderhoude met die leerders te vergelyk met die navorsingsverslae van die deelnemers. Die navorsingsvraag, soos aangedui in die inleiding van die artikel, is gebruik as raamwerk vir die uitvoering van die navorsing. ' $n$ Beperking van die studie is dat die instruksies van die navorsingsopdrag aan die deelnemers moontlik nie duidelik gestel is nie. Hoewel die deelnemers die gebruik van kulturele artefakte in die voorbereiding en aanbieding van lesse moes insluit, het die navorser nie van studente verwag om lesplanne as databronne in te handig nie. Die meeste data wat ingehandig is, was nie bruikbaar nie en daar was 'n gebrek aan diepte.

\section{Insameling van data: Navorsingsverslae en onderhoude}

Die honneursstudente in wiskunde-onderwys het 'n opdrag in hul navorsingsmetodologiemodule ontvang om navorsing te doen oor die gebruik van kulturele artefakte in enige wiskunde-onderwerp in die wiskundekurrikulum. Hulle moes 'n les voorberei en aanbied waarin kulturele artefakte gebruik is. Hulle moes die kulturele artefakte identifiseer, dit in ' $n$ wiskundeles insluit en leerders se ervaring van dit ondersoek. Deelnemers het 'n keuse gehad watter data-insamelingsinstrumente hulle wou gebruik, maar moes, onder andere, onderhoude met leerders gevoer het om hul ervarings van die gebruik van kulturele artefakte vas te stel. Die deelnemers moes hul bevindings in 'n navorsingsverslag aanteken wat hulle elektronies op 'n laserskyf ingehandig het. Die studente is begelei in terme van die stappe wat hulle moes volg om die navorsingsverslag voor te berei. Eerstens moes die honneursstudente die opdrag in 'n navorsingsvraag omskep en 'n agtergrond skep waarteen die navorsingsvraag tot sy reg sou kom. Daarna moes lesplanne ontwikkel word om die probleem aan te pak. Deelnemers moes literatuur ondersoek om ingeligte besluite ten opsigte van hul voorbereiding van lesse te neem oor hoe hulle kulturele artefakte in hul wiskundelesse wou gebruik. Lesse moes die kurrikulum relevant, interessant en aantreklik vir leerders maak. Data moes ingesamel en geanaliseer word en bevindings moes aangeteken word. Die data is verkry deur middel van waarneming tydens klasaktiwiteite, ondersoeke en vraelyste, die gebruik van kulturele artefakte (soos kleredrag, speletjies en voorwerpe) in hul onderrig, toetsresultate en onderhoude. Deelnemers moes die onderhoude wat hulle met leerders gevoer het, transkribeer en die inhoud as 'n bylaag aan hul navorsingsverslag heg. 
Die navorser het vir hierdie manuskrip deelnemers se navorsingsverslae en die getranskribeerde onderhoude as data-insamelingsinstrumente gebruik. Slegs die bevindings in die navorsingsverslae en die onderhoude is geanaliseer om voorbeelde van kulturele artefakte in die voorbereiding van 'n wiskundeles te gee, asook om leerders se ervarings te analiseer. ' $n$ Tekortkoming in die studie is dat lesplanne nie beskikbaar was om gedetailleerde voorbeelde weer te gee nie.

\section{Analise van data}

Data vanuit deelnemers se navorsingsverslae en die getranskribeerde onderhoude wat deelnemers met leerders gevoer het, is geanaliseer deur hulle aandagtig deur te lees om 'n holistiese perspektief te kry. Relevante antwoorde is van irrelevante antwoorde geskei. Daarna is Saldana (2009) se oop koderingsmetode gebruik, wat 'n heuristiese ondersoekende probleemoplossingstegniek is sonder spesifieke formules om te volg. Kodes is gebruik om woorde of kort paragrawe te kategoriseer en in temas te plaas. Tabel 2 verteenwoordig die temas, subtemas en kodes wat vanuit die kwalitatiewe analise ontstaan het.

\section{Resultate en interpretasie}

In die volgende bespreking is skuilname vir deelnemers (wiskunde-onderwysstudente) en leerders gebruik om hul identiteite te beskerm, byvoorbeeld deelnemer 1, deelnemer 2 , ens. vir wiskunde-onderwysstudente en leerder 1, leerder 2, ens. vir leerders. Aanhalings kom vanuit navorsingsverslae van deelnemers en getranskribeerde onderhoude met leerders, soos ingehandig in Oktober 2013.

Deelnemers het verskillende voorbeelde van kulturele artefakte in die voorbereiding van wiskundelesse gebruik, soos kulturele vestings, kledingstukke, speletjies en kunswerke.

\section{Kulturele vestings}

Beide deelnemers 5 en 9 het aangetoon dat hulle tradisionele Venda-hutte (rondawels) gebruik het om probleme in meting te verduidelik. Deelnemer 5 het rondawels gebruik om volume en buite-oppervlakte van sfere, piramides en keëls in graad 11-wiskunde te onderrig, terwyl deelnemer 9 hulle gebruik het om oppervlaktes van sirkels in graad 10 te onderrig (DBO 2011b:15). Volgens hom het 'n rondawel

TABEL 2: Temas, subtemas en kodes.

\begin{tabular}{lll}
\hline Temas & Sub-temas & Kodes \\
\hline $\begin{array}{l}\text { Praktiese voorbeelde in 'n } \\
\text { kulturele konteks }\end{array}$ & Kulturele vestings & Rondawels \\
& Kleredrag & Hoed \\
& & Zoeloe-kleredrag \\
& Xhosa se kulturele drag \\
& Speletjies & Diketo \\
& & Uuca \\
& & Morabara \\
& Umlabalaba \\
& Kunswerk & Venda-kleikuns \\
\hline
\end{tabular}

'n deursnee, hoogte en omtrek. Om die oppervlakte van 'n sirkel te bereken, moes leerders eers die radius bereken deur die deursnee te meet met behulp van 'n maatband en dan die deursnee in twee gelyke lengtes te verdeel. Leerders moes die formule vir die oppervlakte van 'n sirkel ken, naamlik $A=\pi r^{2}$, waar $\pi \approx 3.14$ en $r=$ radius van die sirkel. Nadat die radius bepaal is, was dit maklik om die oppervlakte van die sirkel te bepaal. Huffman (2005) beskryf 'n rondawel as 'n keël op 'n silinder, of 'n keël op 'n drom, wat 'n sirkelvormige gebou met ' $n$ grasgedekte dak is en in die verlede as 'n melkplek, stoorkamer, linnekamer of huis gebruik is. Bogenoemde deelnemers het nie onderhoude met leerders gevoer nie.

\section{Kledingstukke}

Deelnemer 7 verwys in sy navorsingsverslag na die SuidSotho's se mokoro ('n keëlvormige hoed) wat hy gebruik het in sy onderrig van driedimensionele vorms in die oplossing van probleme wat oor volume en die buiteoppervlakte van vaste stowwe handel (DBO 2011a:15). Volgens Wong (2005) is die prikkeling van leerders se nuuskierigheid deur die onderrig van probleemoplossing in 'n kulturele konteks 'n kragtige onderrigstrategie. Onderwysers kan probleme op leerders se kennisvlak stel en hulle deur stimulerende vrae lei tot die oplossing daarvan (Wong 2005). Dié deelnemer het nie 'n onderhoud met leerders gevoer nie.

Deelnemer 2 dui aan dat sy die isidwaba ('n vroulike kledingstuk in die Zoeloe-kultuur) gebruik het om die sinusreël in graad 11 wiskunde te verduidelik (DBO 2011b:15). ' $\mathrm{n}$ Tekortkoming in die data is dat deelnemer 2 nie verduidelik het hoe sy die kledingstuk met die sinusreël verbind het nie. Uit haar onderhoude blyk dit egter dat leerders dit van waarde geag het:

Leerder 1 meld:

'My view is that if we use cultural artefacts more [regularly] in mathematics we can understand better, because it's everything we see every day. If you forget at home uzophinde uyibonefuthi (you will see it again). So if we use it more in sine rule we are going to pass.' (Leerder 1, dogter, graad 11)

Leerder 2 noem:

'Most of us we really enjoyed that topic, $\mathrm{mmm}$... $\mathrm{mmm} \mathrm{I}$ had never thought that traditional dressing could be used in a mathematics classroom. Everyone was talking about it, such things makes mathematics to be live. Now I know even if I am at home, that anything in my house could be linked to mathematics.' (Leerder 2, seun, graad 11)

Volgens Nkumane (2001) is vroulike kleredrag belangrik in die Zoeloe-kultuur. Zoeloevroue word in ses kategorieë geklassifiseer, naamlik intombizane ('n jong dogter), itshitshi ('n tienerdogter), iqhikiza ('n volwasse dogter), ingodusi ('n verloofde vrou), umalokazana ('n bruid) en inkosi kazi ('n getroude vrou). Elkeen van hierdie kategorieë het sy eie kulturele drag, maar daar is 'n gemeenskaplike kledingstuk tussen die iqhikiza, ingodusi, 
umalokazana en inkosi kazi, naamlik die isidwaba. Dit verskil slegs in lengte en is aanvanklik van bokvelle gemaak, maar word deesdae deur komberse vervang (Nkumane 2001). Volgens Abramovich (2000) ervaar leerders wiskunde in 'n genotvolle omgewing waar kulturele artefakte gebruik word, as iets wat hulle doen, eerder as iets wat hulle moet memoriseer.

Deelnemer 8 het aangedui dat sy die Xhosas se kulturele kleredrag gebruik het om 'n konteks te skep om transformasie in graad 8 wiskunde te verduidelik (DBO 2011a:29). Volgens haar sluit transformasie fisiese manipulasie van vorms tot nuwe oriëntasies of posisies in en kan drie tipes bewegings onderskei word, naamlik verplasings, refleksies en rotasies. Hoewel sy nie aangetoon het hoe sy die kulturele artefakte met transformasie in verband gebring het nie, het haar leerders in die onderhoude aangetoon dat hulle kan onderskei tussen die tipe bewegings:

Leerder 5 meld:

'Before my teacher used cultural artifacts, I really did not grasp the difference between the term transformation and translation. I totally confused the two terms but now I understand the difference.' (Leerder 5, seun, graad 8)

\section{Leerder 6 noem:}

'Now madam, every time I look at cultural clothing, I am always looking for the transformation I can spot. I am no longer just looking at the beauty but now I look for mathematics that I can find.' (Leerder 6, seun, graad 8)

\section{Speletjies}

Deelnemer 1 het diketo, 'n Pedi-speletjie, gebruik om 'n les in lineêre grafieke voor te berei. Volgens haar moet onderwysers voortdurend reflekteer oor die effektiwiteit van onderrigstrategieë wat gebruik word om grafieke in graad 9 te onderrig. Sy argumenteer dat onderwysers soms basiese vaardighede en konsepte onderskat wanneer leerders onderrig word om lineêre grafieke te skets en te interpreteer. Die KABV spesifiseer dat leerders verskillende beskrywings van dieselfde verhouding of reël, voorgestel in tabelle en grafieke op 'n Kartesiese vlak, moet kan bepaal en interpreteer (DBO 2011a:22). Volgens deelnemer 1 help diteko met die vaardighede om data vanuit tabelle op 'n Kartesiese vlak voor te stel, koördinate te verbind en grafieke te interpreteer. Deelnemer 1 het diteko gebruik om leerders te help om te verstaan dat die gradiënt van 'n lyn óf positief óf negatief is. Diketo is 'n speletjie wat met klippies gespeel word en koördinasievaardighede ontwikkel. Die doel van die speletjie is om die meeste klippies te versamel. 'n Gat word in die grond gemaak en gevul met 'n aantal klippies. 'n Klippie word in die lug gegooi, terwyl al die klippies uit die gat geskep word en die klippie wat in die lug gegooi is, gevang word. 'n Klippie word weer in die lug gegooi. Weereens word al die klippies teruggeskep in die gat, behalwe een klippie. Die oefening word herhaal, en die persoon wen wat die meeste klippies versamel. Soos die getal gooie vermeerder, neem die getal geskepte klippies ook toe, dus 'n positiewe gradiënt. 'n Gradiënt word bepaal deur die verhouding van vertikale en horisontale veranderlikes. Die resultate word in ' $n$ tabel aangeteken, waar die boonste ry $x$-waardes en die onderste ry $y$-waardes voorstel. Vanuit die tabel kan afgelei word of die gradiënt positief of negatief is, waarna die punte op 'n Kartesiese vlak voorgestel kan word. Deelnemer 1 het die volgende voorbeeld aangeheg:

Twee leerders het in 'n diketo-speletjie gekompeteer en hul resultate is in die volgende tabel aangeteken:
Getal gooie (x)
Getal geskepte klippe

$\begin{array}{lllll}1 & 2 & 3 & 4 \\ 2 & 4 & 6 & \end{array}$
6
a) Voltooi die tabel.
b) Stel die inligting op 'n Kartesiese vlak voor.
c) Watter tipe verhouding word in die grafiek aangedui? Gee 'n rede vir jou antwoord.

Bogenoemde waardes is egter fiktiewe waardes. Diketo lewer nie noodwendig direkte eweredigheidsresultate nie, aangesien die klippie wat in die lug gegooi is, soms nie gevang kan word nie, of al die klippies nie betyds uit die gat geskep kan word nie, of meer as een klippie buite die gat gelos word.

Deelnemer 11 het dieselfde speletjie gebruik om getalpatrone in graad 9 te verduidelik (DBO 2011a:10), maar volgens haar staan dit bekend as upuca in die Xhosa-kultuur.

Volgens deelnemer 4 het hy morabaraba (Sepedi-speletjie) (Figuur 2) gebruik vir die onderrig van meetkunde in graad 10 , spesifiek vir die ondersoek van lynsegmente wat met die middelpunte van twee sye van 'n driehoek verbind is (DBO 2011b:14).

Volgens deelnemer 4 word morabaraba deur twee leerders, elk met 12 klippies, of enige ander voorwerp gespeel. Die klippies

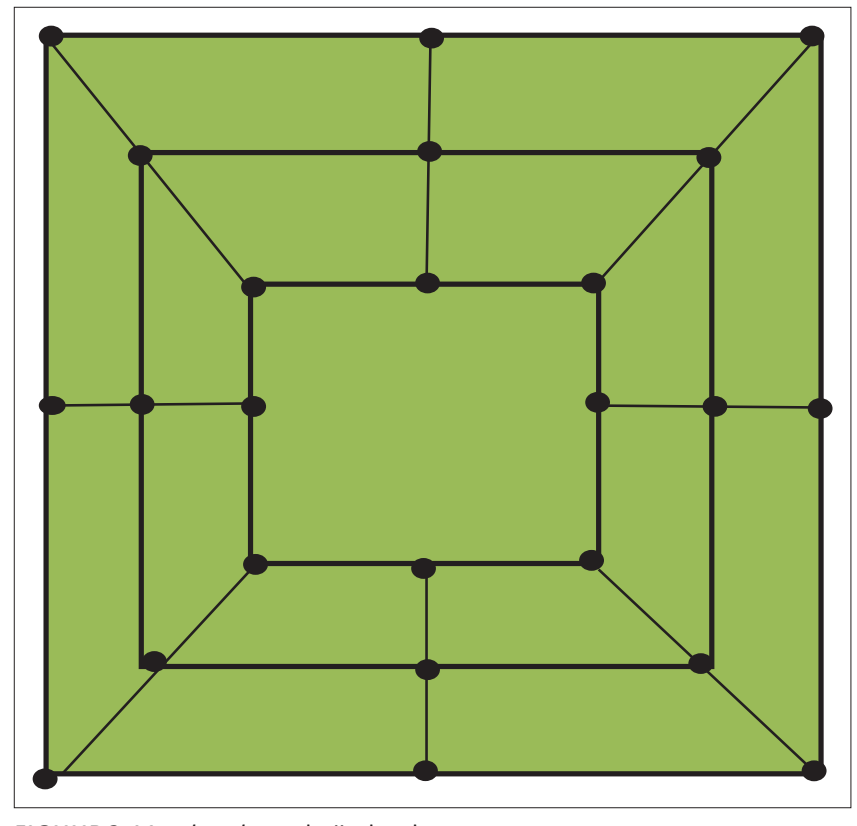

FIGUUR 2: Morabaraba speletjiesbord. 
verteenwoordig beeste. Die klippies van die opponente moet verskil in kleur of vorm. Tydens elke ronde word 'n bees op die speletjiesbord geplaas en mag slegs op leë plekke geplaas word. Spelers probeer om 'n kolom, middellyn of 'n ry met drie beeste vorm. Indien 'n lyn gevorm word, kan die speler een van sy opponent se beeste skiet. Die dooie bees word van die bord verwyder en mag nie weer gebruik word nie. 'n Bees wat in 'n lyn is, mag nie geskiet word nie, buiten as al die opponent se beeste in 'n lyn is. 'n Speler wen wanneer die opponent geen skuif meer kan maak nie. Deelnemer 4 argumenteer dat wiskundige beginsels soos getalle, simmetrie, meetkundige vorms, verhoudings en logiese denke deur middel van die speletjie ontwikkel. Volgens deelnemer 3 het bevolkingsgroepe verskillende name vir morabaraba, naamlik umlabalaba (Nguni), dizela (Tsonga) en izingedo (Zoeloe). Hy het nie aangedui hoe hy morobaraba met meetkunde in graad 10 verbind het nie. Deelnemer 10 het gemeld dat sy umlabalaba gebruik het om analitiese meetkunde in graad 10 te onderrig, veral met ' $n$ fokus op die afstand tussen twee punte, die gradiënte en die middelpunt, maar het nie verdere data verskaf nie (DBO 2011b:15).

Deelnemer 4 het leerders gevra om die speletjie se diagram met bordkryt op hul tafels te trek en het die speletjie die eerste 10 minute van die les gespeel. Daarna het hy die speletjie en diagram met wiskundige konsepte verbind. Deelnemer 4 was besorg oor die tyd wat die gebruik van kulturele artefakte in beslag neem en het in sy navorsingsverslag genoem:

'... learners are fully much aware of the game and how its sketch is drawn. But the challenge was time; I did not complete what I normally complete on this topic and I am afraid that I will remain behind according to pace setter, but I am bit hopeful that they understood.' (Deelnemer 4, manlik, onderwyser)

Nkopodi en Mosimege (2009) noem dat die speletjies in baie ander lande in Suider-Afrika soos Lesotho, Botswana, Mosambiek en Zimbabwe gespeel word en wiskundige vaardighede ontwikkel.

\section{Kunswerke}

Volgens deelnemer 3 het hy Venda-kleikuns gebruik om meetkundige patrone in graad 7 te onderrig (DBO 2011a:10), maar het nie aangedui hoe hy dit gebruik het nie. Vanuit sy onderhoude met leerders blyk dit dat hulle dit genotvol gevind het en dat dit bygedra het tot innovering:

Leerder 3 het sy ervaring soos volg beskryf:

'Wow ... It was a wonderful experience having to learn geometric patterns using the clay. I have managed to be more creative and innovative towards designing my own geometric patterns.' (Leerder 3, manlik, graad 7)

Leerder 4 het gemeld:

'I have enjoyed using clay art to learn geometric patterns. I was actively involved and able to be creative in terms of designing my own geometric patterns that culturally related.' (Leerder 4, vroulik, graad 7)
Abramovich (2000) beaam dat kulturele artefakte interaktiewe eksperimentering met wiskundige vakinhoud aktiveer en 'n ondersoekende werkwyse bevorder.

Vanuit bogenoemde voorbeelde blyk dit dat wiskunde aan die hand van kulturele artefakte meer konkreet en gekontekstualiseer onderrig kan word en wiskundelesse daarvolgens aangepas kan word.

\section{Gevolgtrekking en aanbevelings}

Uit die navorsing wat hier aangebied is, is voorbeelde van kulturele artefakte uitgewys wat gebruik kan word in die voorbereiding van 'n wiskundeles deur onderwysers in Suid-Afrika. Die navorsing het ook meer blootstelling aan etnowiskunde gegee. Etnowiskunde is die wiskunde wat wiskundige konsepte en praktyke van verskillende kulture in formele skoolwiskunde integreer en leerders die geleentheid bied om die verband tussen wiskunde en die onderskeie kulture te sien deur wiskundige konsepte in onderliggende kulturele artefakte te ondersoek. Onderwysers is bewus gemaak daarvan dat wiskunde 'n menslike aktiwiteit is met kulturele inhoud of waardes (Wong 2005). Die gebruik van kulturele artefakte in die wiskundeklas skep 'n stimulerende leeromgewing en bevorder kulturele waardering. Etnowiskunde stel 'n onderwyser verder in staat om wiskunde op 'n verbeeldingryke en kreatiewe wyse aan te bied, terwyl diversiteit sinvol gehanteer word.

Die doel van die artikel was om voorbeelde van kulturele artefakte in die voorbereiding van 'n wiskundeles te identifiseer ten einde wiskunde meer betekenisvol en kontekstueel aan leerders te onderrig. Voorbeelde wat gebruik is, is geïdentifiseer deur wiskundeonderwysstudente wat deeltyds vir 'n B.Ed.-honneursgraad in Wiskunde-onderwys by ' $n$ universiteit ingeskryf is. Daar is bevind dat verskillende voorbeelde van kulturele artefakte gebruik is in die voorbereiding van wiskundelesse, naamlik kulturele vestings, kledingstukke, speletjies en kunswerke. Die bevindings kan nie veralgemeen word nie, aangesien die navorsing slegs by een universiteit uitgevoer is en die steekproef klein was. Verdere navorsing oor die toepassing van voorbeelde van die gebruik van kulturele artefakte in die voorbereiding van wiskundelesse is nodig, asook in onderrigstrategieë om etnowiskunde te onderrig om sodoende ons wiskunde-onderrigpraktyke in Suid-Afrika te bevorder.

\section{Erkenning}

Die navorser is dankbaar teenoor die wiskundeonderwysstudente vir hul deelname aan en samewerking in die navorsing. 'n Spesiale woord van dank word ook gerig aan prof. Josef de Beer van die Universiteit van Noordwes vir sy kundige advies en ondersteuning, asook aan dr. Maretha Gous vir die taalkundige versorging van die artikel. Sonder die finansiering van die Universiteit van Johannesburg sou die navorsing nie moontlik gewees het nie. 


\section{Mededingende belange}

Die outeur verklaar hiermee dat sy geen finansiële of persoonlike verbintenis het met enige party wat haar nadelig of voordelig kon beïnvloed het in die skryf van hierdie artikel nie.

\section{Literatuurverwysings}

Abramovich, S., 2000, Cultural tools and mathematics teacher education, State University of New York, Potsdam, NY, viewed 08 September 2015, from http:// www2.potsdam.edu/EDUC/abromovs

Adam, S., Alangui, W. \& Barton, B., 2003, 'A comment on: Rowlands \& Carson "Where would formal, academic mathematics stand in a curriculum informed by ethnomathematics? A critical review"', Educational Studies in Mathematics 52, 327-335. http://dx.doi.org/10.1023/A:1024308220169

Adler, J. \& Davis, Z., 2006, 'Opening another black box: Researching mathematics for teaching in mathematics teacher education', Journal for Research in Mathematics Education 37(4), 270-296. viewed 01 July 2014, from http://www.jstor.org/stable/ 30034851

Ascher, M. \& D'Ambrosio, U., 1994, 'Ethnomathematics: A dialogue', For the Learning of Mathematics 14(2), 36-43, viewed 30 June 2014, from http://flm-journal.org// FLMDAmbrosio.pdf

Bangura, A.K., 2012, African mathematics: From bones to computers, University Press of America Inc., Maryland.

Bernstein, A., 2011, 'Value in the classroom: The quantity and quality of South Africa's teachers', (CDE In Depth no. 11), The Centre for Development and Enterprise, Johannesburg.

Bishop, A.J., 1991, Mathematical enculturation: A cultural perspective on mathematics education, Kluwer Academic Publishers, Norwell, MA.

Bohlmann, C. \& Pretorius, E., 2008, 'Relationships between mathematics and literacy: Exploring some underlying factors', Pythagoras 67, 42-55. http://dx.doi. org/10.4102/pythagoras.v0i67.73

Bullivant, B.M., 1987, The ethnic encounter in the secondary school. Ethnocultural reproduction and resistance; theory and case studies, The Falmer Press, London.

Creswell, J.W., 2003, Research design: Qualitative, quantitative and mixed methods approaches, 2nd edn., Sage, Thousand Oaks, CA

D'Ambrosio, U., 1985, 'Ethnomathematics and its place in the history and pedagogy of mathematics', For the Learning of Mathematics 5(1), 44-48, viewed 12 March 2014 from http://www.jstor.org/stable/40247876

D'Ambrosio, U., 1989, 'A research program and a course in the history of mathematics: Ethnomathematics', Historia Mathematica 16(3), 285-287. http://dx.doi. org/10.1016/0315-0860(89)90026-8

D'Ambrosio, U., 1990, 'The role of mathematics education in building a democratic and just society', For the Learning of Mathematics 10(3), 20-23, viewed 30 June 2014, from http://www.jstor.org/stable/40247989

De Beer, J.J. \& Van Wyk, B-E., 2012, 'Inheemse kennis in die lewenswetenskappeklaskamer: Wetenskap, pseudo-wetenskap, of 'n vermiste skakel?' SuidAfrikaanse Tydskrif vir Natuurwetenskap en Tegnologie 31(1), 1-5. http://dx.doi. Afrikaanse Tydskrif vir Natuu
org/10.4102/satnt.v31i1.368

Departement van Basiese Onderwys, 2011a, Kurrikulum- en assesseringsbeleidsverklaring. Grade 7-9. Wiskunde, Pretoria, besigtig op 14 Augustus 2015 van http://www.education.gov.za/LinkClick.aspx?fileticket=QPqC7QbX75w\%3d\& tabid=420\&mid=1216

Departement van Basiese Onderwys, 2011b, Kurrikulum- en assesseringsbeleidsverklaring Grade 10-12, Wiskunde Pretoria, besigtig op 14 Augustus 2015, van http://www.education.gov.za/LinkClick.aspx?fileticket=QPqC7QbX75w $\% 3 \mathrm{~d} \&$ tabid $=420 \&$ mid $=1216$
Frenzel, A.C., Pekrun, R. \& Goetz, T., 2007, 'Perceived learning environment and students' emotional experiences: A multilevel analysis of mathematics classrooms', Learning and Instruction 17, 478-493. http://dx.doi.org/10.1016/j. classrooms', Learning and

Guba, E.G., 1981, 'Criteria for assessing the trustworthiness of naturalistic inquiries', Educational communication and technology 29(2), 75-91. http://dx.doi. org/10.1007/BF02766777

Hall, P.M., 1997, Race, ethnicity and multiculturalism. Policy and practice, Garland Publishing Inc., New York, NY.

Hlalele, D., 2012, 'Exploring rural high school learners' experiences of mathematics anxiety in academic settings', South African Journal of Education 32(3), 267-278.

Huffman, T.N., 2005, Mapungubwe: Ancient African civilisation on the Limpopo, Wits University Press, Johannesburg.

Leonard, J., 2008, Culturally specific pedagogy in the mathematics classroom. Strategies for teachers and students, Routledge, New York, NY.

Moloi, M. \& Strauss, J., 2005, The SACMEQ II project in South Africa: A study of the conditions of schooling and the quality of education, SACMEQ, Harare.

Mouton, J., 2001, How to succeed in your master's \& doctoral studies, Van Schaik, Pretoria.

Namukasa, I., 2004, 'School mathematics in the era of globalization', Interchange 35(2), 209-227. http://dx.doi.org/10.1007/BF02698850

Nkopodi, N. \& Mosimege, M., 2009, 'Incorporating the indigenous game of morabaraba in the learning of mathematics', South African Journal of Education 29 , 377-392, viewed 08 September 2015, from http://www.scielo.org.za/scielo. php?pid=S0256-1002009000300006\&script=sci_arttext

Nkumane, G., 2001, 'The traditional dress of the Zulu woman: A return to the roots', Indigenous Knowledge Conference, viewed 08 September 2015, from http:// iportal.usask.ca/purl/IKC-200Nkumane.pdf

NNS (Nasionale Navorsingstigting), 2012, Indigenous knowledge systems, knowledge fields development (KFD), CSIR, Pretoria.

Rowley, J., 2002, 'Using case studies in research', Management Research News 25, $16-27$.

Rosa, M. \& Orey, D.C., 2011, 'Ethnomathematics: The cultural aspects of mathematics', Revista Latinoamericana de Etnomatemática 4(2), 32-54.

Rowlands, S. \& Carson, R., 2002, 'Where would formal, academic mathematics stand in a curriculum informed by ethnomathematics? A critical review of ethnomathematics', Educational Studies in Mathematics 50, 79-102. http:// dx.doi.org/10.1023/A:1020532926983

Saldana, J., 2009, The coding manual for qualitative researchers, Sage, London.

Selin, H. (ed.), 2000, Mathematics across cultures. The history of non-Western mathematics, Kluwer Academic Publishers, Dordrecht.

Soanes, C. (ed.), 2002, Pocket oxford English dictionary, 9th edn., Oxford University Press, New York, NY.

Spaull, N., 2013, 'South Africa's education crisis: The quality of education in South Africa 1994-2011', Centre for Development \& Enterprise, viewed 08 September 2015, from http://www.section27.org.za/wp-content/uploads/2013/10/Spaull2013-CDE-report-South-Africas-Education-Crisis.pdf

Vandeyar, T., 2010, The appropriation of education policy on information and communication technology in South African schools, PhD thesis, Department of Mathematics, Science and Technology Education, University of Pretoria, Pretoria, viewed 30 September 2015 from http://hdl.handle.net/2263/25178

Venkat, H., 2007, 'Mathematical literacy - Mathematics and/or literacy: What is being sought?', Pythagoras 66, 52-63. http://dx.doi.org/10.4102/pythagoras.v0i66.82

Wilson, M., 2002, 'Six views of embodied cognition', Psychonomic Bulletin \& Review 9(4), 625-636. PMID: 12613670, http://dx.doi.org/10.3758/BF03196322

Wong, K.Y., 2005, 'Add cultural values to mathematics instruction: A Singapore initiative', paper presented at the conference proceedings of the 4th Asian Mathematical conference held in Singapore, conducted by Mathematics and Mathematics Education Academic Group, National Institute of Education, Nanyang Technological University, Singapore, 20-23 July. 